\title{
Patch dynamics and the development of structural and spatial heterogeneity in Pacific Northwest forests
}

\author{
Van R. Kane, Rolf F. Gersonde, James A. Lutz, Robert J. McGaughey, \\ Jonathan D. Bakker, and Jerry F. Franklin
}

\begin{abstract}
Over time, chronic small-scale disturbances within forests should create distinct stand structures and spatial patterns. We tested this hypothesis by measuring the structure and spatial arrangement of gaps and canopy patches. We used airborne LiDAR data from 100 sites (cumulative $11.2 \mathrm{~km}^{2}$ ) in the Pacific Northwest, USA, across a 643 year chronosequence to measure canopy structure, patch and gap diversity, and scales of variance. We used airborne LiDAR's ability to identify strata in canopy surface height to distinguish patch spatial structures as homogeneous canopy structure, matrixpatch structures, or patch mosaics. We identified six distinct stand structure classes that were associated with the canopy closure, competitive exclusion, maturation, and three patch mosaics stages of late seral forest development. Structural variance peaked in all classes at the tree-to-tree and tree-to-gap scales $(10-15 \mathrm{~m})$, but many sites maintained high variance at scales $>30 \mathrm{~m}$ and up to $200 \mathrm{~m}$, emphasizing the high patch-to-patch heterogeneity. The time required to develop complex patch and gap structures was highly variable and was likely linked to individual site circumstances. The high variance at larger scales appears to be an emergent property that is not a simple propagation of processes observed at smaller spatial scales.
\end{abstract}

Résumé : Avec le temps, les perturbations chroniques à petite échelle devraient engendrer différentes organisations spatiales et structures de peuplement. Nous avons testé cette hypothèse en mesurant la structure et l'organisation spatiale des trouées et des îlots de forêt. Nous avons utilisés les données LiDAR aéroporté de 100 stations (superficie cumulée de 11,2 km²) dans le Pacific Northwest, aux États-Unis, le long d'une chronoséquence de 643 ans pour mesurer la structure du couvert, la densité des îlots et des trouées et les échelles de variation. Nous avons utilisé la capacité du LiDAR aéroporté à identifier les strates parmi les hauteurs de la surface du couvert pour distinguer les structures spatiales des îlots en tant que structure homogène du couvert, structures de matrice d'îlots ou mosaïques d'îlots. Nous avons identifié six classes différentes de structure de peuplement associées à la fermeture du couvert, à l'exclusion par la compétition, à la maturation et à trois stades de mosaïques d'îlots appartenant aux derniers stades de succession dans le développement de la forêt. La variation structurale a atteint un sommet dans toutes les classes aux échelles d'arbre en arbre et d'arbre en trouée (10-15 m), mais plusieurs stations ont conservé une forte variation à des échelles $>30 \mathrm{~m}$ et jusqu'à $200 \mathrm{~m}$, faisant ressortir la grande hétérogénéité d'un îlot à l'autre. Le temps requis pour développer des structures complexes de trouées et d'îlots était très variable et probablement relié aux circonstances propres à chaque station. La forte variation aux échelles plus grandes semble être une propriété émergente qui n'est pas une simple propagation des processus observés à de plus petites échelles spatiales.

[Traduit par la Rédaction]

\section{Introduction}

The theory of patch dynamics has been one of the most influential concepts in vegetation ecology. Watt (1947) recognized that small-scale disturbances of the dominant vegetation would result in the creation of gaps leading to mosaics of plant communities. Following disturbance, gaps begin as distinct, high-contrast canopy structures that over time become more structurally similar to the surrounding canopy structure as trees colonize the gap from below or encroach the gap from the adjacent canopy. Disturbances, either mortality of canopy trees or abrupt canopy dieback, release resources that become available to sub-canopy trees or to those canopy trees adjacent to the disturbance. In forests, gaps are recognized as sites of regeneration in which new cohorts of trees emerge into the forest overstory (Connell 1989).

Researchers have shown that gap formation is a continuous process. Runkle (1982) found that new gaps annually represented $0.5 \%-2 \%$ of his study areas in temperate old-growth

Received 10 February 2011. Accepted 14 August 2011. Published at www.nrcresearchpress.com/cjfr on 9 November 2011.

V.R. Kane, J.A. Lutz, J.D. Bakker, and J.F. Franklin. School of Forest Resources, College of the Environment, University of Washington, Box 352100, Seattle, WA 98195, USA.

R.F. Gersonde. Watershed Services Division, Seattle Public Utilities, 19901 Cedar Falls Road SE, North Bend, WA 98045, USA.

R.J. McGaughey. Pacific Northwest Research Station, USDA Forest Service, University of Washington, Box 352100, Seattle, WA 98195, USA.

Corresponding author: Van R. Kane (e-mail: vkane@u.washington.edu). 
forests in seven dispersed locations in the eastern United States. Runkle (1982) identified a lognormal frequency distribution of gap sizes as evidence of chronic small-scale disturbances rather than periodic large-scale disturbances. Similar results have been observed in hemlock-hardwood forests of upper Michigan State, USA (Frelich and Lorimer 1991), southern boreal forests in Minnesota (Frelich and Reich 1995), conifer forests of the Pacific Northwest (Spies et al. 1990; Lertzman et al. 1996), hardwood forests in New England (Fraver et al. 2009), mixed-wood boreal forests (Vepakomma et al. 2010), and Nothofagus forests of South America (Rebertus and Veblen 1993). These studies demonstrate the importance of frequent, small-scale disturbances in creating structure in forests that lack periodic stand-replacing disturbances such as fire or hurricanes.

The mechanisms of gap development involve both biological and physical disturbance agents. Root, butt, and stem decay fungi and insects such as bark beetles are common biological disturbance agents in the Pacific Northwest (Franklin et al. 2002). Studies in both young forests (15-40 years) and old forests (>200 years) show that gap formation can also involve physical disturbance agents such as wind operating at multiple spatial scales (Lutz and Halpern 2006; Larson and Franklin 2010).

Over time, gap formation and subsequent regrowth within a stand should approach the quasi-equilibrium landscape of successional stages suggested by several authors (Bormann and Likens 1979; Shugart 1984) and predicted by modeling (Smith and Urban 1988). The state of any given location would be difficult to predict because disturbances are stochastic, but the mean successional direction of a stand would be predictable (Smith and Urban 1988). An empirical test of this theory could be accomplished by an analysis of gap and patch structure in stands of multiple developmental stages with replicated study sites. Patches would be the basic spatial unit representing areas of similar structure, while stands would be emergent structures composed of one or more patches. (An emergent property is a complex pattern that develops from simpler processes.) A low-complexity stand might have a single to a few large patches, while a high-complexity stand might have a fine-scale mosaic of many patch types.

Although the mechanisms and rates of gap formation are well understood, the spatial patterns of gaps mostly have received qualitative assessments. Frelich and Reich (1995) interpreted patch structure based on subjective descriptions of spatial structure patterns (their fig. 2). Similarly, small-scale horizontal heterogeneity is recognized as a defining characteristic of old-growth stands (Franklin and Spies 1991; Spies 1997; Franklin et al. 2002; Franklin and Van Pelt 2004), but the distribution, size, and variation of gaps have not been quantified.

The lack of quantitative studies of gap and patch spatial patterns is unfortunate. The spatial arrangement of the patches has important consequences for numerous ecosystem functions including provision of habitat for biota, productivity, and regulation of nutrient and water cycles that in turn influences ecosystem resilience because patches of different structure and composition vary in response to disturbance agents (Carey et al. 1999; Jentsch et al. 2002). The spatial scales of gaps and patches also relate to scales of processes governing stand development and ecosystem function (McIntire and Fajardo 2009).

In this study, we mapped the spatial arrangement of gaps and patches as well as the canopy height within gaps to address the question of how the processes of patch dynamics cumulatively structure forest stands. Data from airborne LiDAR provided both the resolution and the wide coverage needed to study gap and patch structure within stands across multiple replicates. While field studies identify gaps and patches from the ground and use the size and location of tree stems to infer past disturbance and regrowth patterns, LiDAR studies identify gaps and patches from above using the arrangement of canopy structure to infer past disturbance and regrowth patterns. We used LiDAR data from 100 sites (cumulative area of $11.21 \mathrm{~km}^{2}$ ) in the Pacific Northwest, USA, across a 643 year chronosequence to address three questions: what was the range of stand structure, as measured by canopy structure, present across the study sites and could they be classified into distinct structural classes, how were gaps and patches arranged within stands, and what do these results suggest about the patch dynamics processes structuring forests?

\section{Methods}

\section{Study area}

The 36679 ha Cedar River Municipal Watershed is located on the western slope of the Cascade Range in Washington State, USA, approximately $60 \mathrm{~km}$ southeast of the city of Seattle (Fig. 1). The majority of the watershed's forests $(84 \%)$ are second-growth forest $<100$ years old that regenerated naturally (1920s and earlier) or were replanted following harvest (post 1920s) (Erckmann et al. 2000). Sixteen percent of the watershed, primarily at mid- to high elevations, consists of primary forests that are 280-350 years old and appear to have regenerated following widespread stand-replacing fires (Hemstrom and Franklin 1982). One sub-basin survived these disturbances and had a cohort of trees 680 years old.

The study area ranges in elevation from 165 to $1655 \mathrm{~m}$ and contains three conifer-dominated forests zones (Franklin and Dyrness 1988; Henderson et al. 1992). Forests in the Western Hemlock Zone $(<800 \mathrm{~m})$ are initially dominated by Douglas-fir (Pseudotsuga menziesii var. menziesii (Mirbel) Franco) with western hemlock (Tsuga heterophylla (Raf.) Sarg.) and western redcedar (Thuja plicata Donn ex D. Don in Lambert) as either early or late seral components. Forests in the Pacific Silver Fir Zone (800-1200 m) are dominated by Pacific silver fir (Abies amabilis (Dougl. ex Loud.) Dougl. ex J. Forbes) and western hemlock. Forests in the Mountain Hemlock Zone $(>1200 \mathrm{~m})$ are dominated by mountain hemlock (Tsuga mertensiana (Bong.) Carrière) and Pacific silver fir. These zones are believed to follow similar sequences of structural development following stand-replacing disturbance. However, the rate at which stands progress through developmental stages is believed to slow with elevation (Franklin and Dyrness 1988; Franklin and Spies 1991; Parish and Antos 2006).

\section{Study sites}

We selected forty-eight 9 ha sites $(300 \mathrm{~m} \times 300 \mathrm{~m})$ within primary forests (no prior timber harvest) and forty-seven 9 ha 
Fig. 1. Shaded relief map of the Cedar River Municipal Watershed in Washington State, USA $\left(47.48^{\circ} \mathrm{N}, 121.98^{\circ} \mathrm{W}\right)$ showing dominant forest zones and study sites. Locations of 9 ha study sites coded as primary (circles) or secondary (squares) forest and by structural class (1-6). Locations of 64 ha study sites with ages in years are also shown.

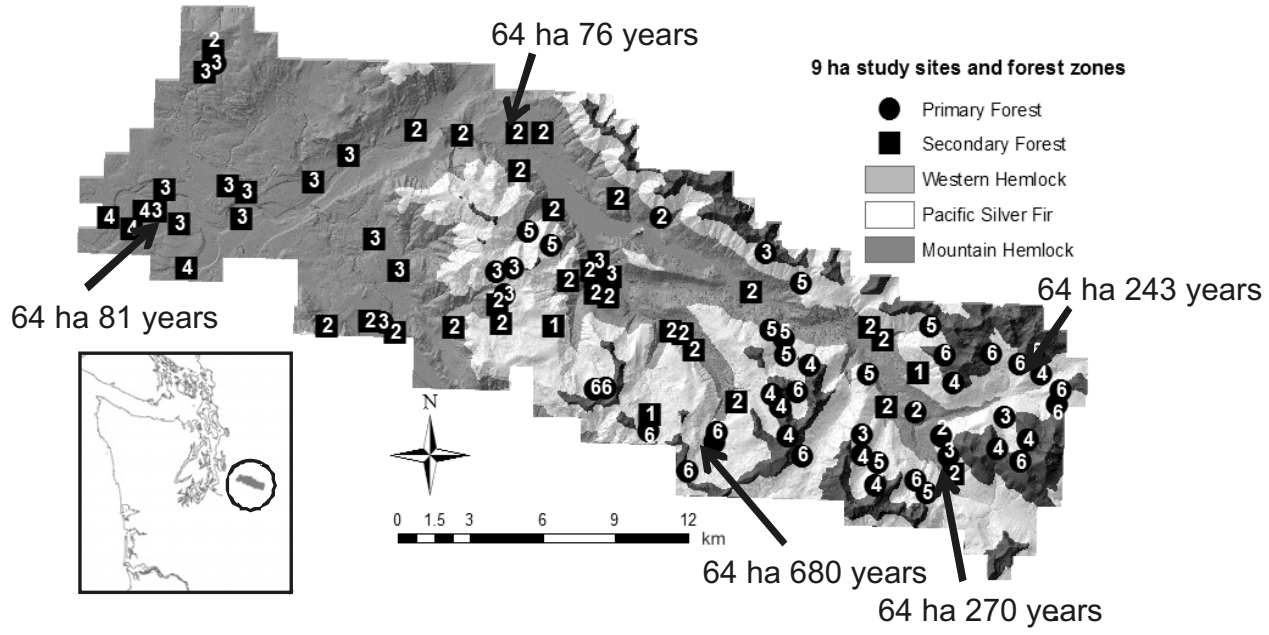

Fig. 2. Distribution of the ninety-five 9 ha study sites by forest zone and age ranges. Timber harvests began in the western lowlands of the watershed in the late 19th century and moved eastward into higher elevations until commercial forest management ceased in 1995. As a result, ages of second-growth forests are correlated with elevation.

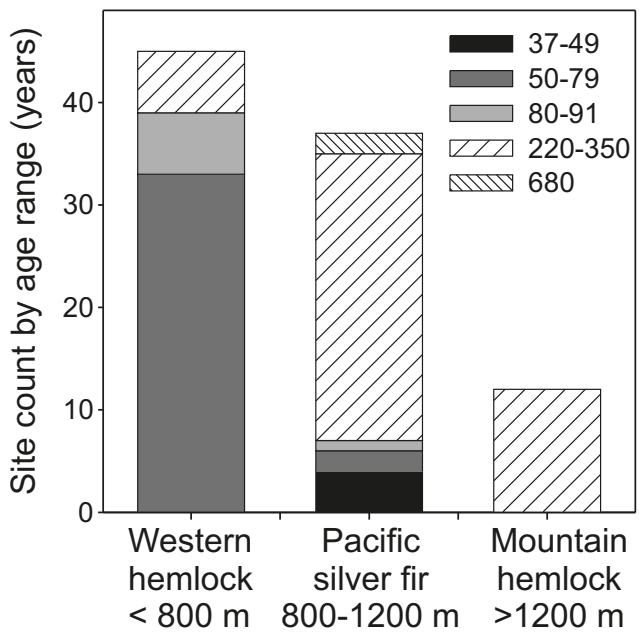

sites within secondary forests to examine within-stand patch structure (Fig. 2). We also selected three 64 ha sites $(800 \mathrm{~m} \times 800 \mathrm{~m})$ within primary forests and two 64 ha sites within secondary forests to study variance in patch structure at larger scales. With overlap between the 9 and 64 ha study sites, the cumulative area of study was $11.21 \mathrm{~km}^{2}$. We used management records, LiDAR metrics, and aerial photographs to select study sites representing a wide range of ages and structural conditions. The number and size of study sites were limited by forest fragmentation caused by harvest history and geomorphology. Study sites were subjectively selected using the following criteria: time since last harvest $\geq 35$ years, the area within secondary sites had to have established within a 5 year period (determined from management records) with no subsequent thinning operations, and the stand did not cross harvest boundaries or major geological discontinuities.

We assigned ages at the time of the LiDAR acquisition to secondary sites based on management records. Age data were available from a limited number of tree cores for the primary sites. As a result, primary sites were assigned to a 220-350 year age range except for the two sites measured to be 680 years old. We relied on the results of two previous studies in this watershed to relate LiDAR measurements to patterns of forest development and forest zone using data from a separate set of 94 permanent sample plots (Kane et al. 2010a, 2010b).

\section{LiDAR data processing}

LiDAR data were collected by Spectrum Mapping, LLC using their DATIS II system during leaf-off conditions over the winter of 2002-2003. Pulse (first-return) point density ranged from 0.4 to $2.7 \cdot \mathrm{m}^{-2}$ with a mean of approximately $1 \cdot \mathrm{m}^{-2}$. To ensure that the considerable variation in multiplereturn proportions across the watershed did not affect the results, we used only the three-dimensional position of the first-return LiDAR data (Kane et al. 2010b).

LiDAR processing was identical to that of Kane et al. $(2010 a)$ and is summarized here. LiDAR data were processed using the FUSION software package (beta version derived from version 2.64; http://forsys.cfr.washington.edu/fusion. html). A $3 \mathrm{~m}$ resolution digital terrain model (DTM) for the watershed was created from the LiDAR point cloud (Kane et al. 2010b). Return heights above ground were used to calculate LiDAR metrics and canopy surface models (CSMs) and were calculated by subtracting the elevation of the underlying DTM from each first return.

CSMs were created for each study site using a $1.5 \mathrm{~m}$ grid cell and a $3 \times 3$ smoothing algorithm to study canopy structure at a fine grain. Smoothing prevented the rumple and wavelet analyses from being biased by small-scale variations in canopy structure and small areas with no LiDAR returns. A separate unsmoothed CSM was created using $3 \mathrm{~m}$ grid cells for the 9 ha study sites to identify canopy patches and 
gaps. The $3 \mathrm{~m}$ grid cell size was chosen so that almost all grid cells would have at least one LiDAR data point representing the canopy height. The few cells missing LiDAR returns were marked as "no data" and were not included in statistical processing. The height assigned to each grid cell in the two CSMs was the maximum return height within the grid cell.

We calculated LiDAR metrics for each 9 ha study area at a scale of $30 \mathrm{~m}$ ( $0.09 \mathrm{ha})$ chosen to approximate the scale of functional forest gaps (Urban et al. 1987). The three LiDAR metrics 95th percentile height, canopy closure, and rumple were selected because they strongly correlate with changes in stand structure as measured with common field metrics (Kane et al. 2010a). These metrics were calculated for the one hundred $30 \mathrm{~m}$ grid cells within each 9 ha study site. Each site was assigned the mean and standard deviation of these metrics.

The 95th percentile height metric was calculated from the point cloud for each $30 \mathrm{~m} \times 30 \mathrm{~m}$ grid cell using all first-return heights in the grid cell. Canopy closure was calculated as the proportion of first returns $>3 \mathrm{~m}$ in height divided by the total number of first returns and measured the proportion of area in which foliage, branches, and stems blocked the ground or low-growing vegetation from the LiDAR instrument. Rumple (canopy rugosity) measured the structural heterogeneity of the canopy surface and correlated with gap and patch structure, disturbance, and regrowth history (Birnbaum 2001; Ishii et al. 2004). Rumple was computed as the surface area of the $1.5 \mathrm{~m}$ CSM divided by the surface area of the underlying DTM.

\section{Classes of stand structure}

To identify patterns of stand structure among our study sites, we classified the ninety-five 9 ha sites based on the mean and standard deviation of the 95th percentile height, canopy closure, and rumple across each study site. Four to eight stand development stages with characteristic forest structures have been identified using commonly developed forest development models for this region (Franklin et al. 2002). We examined classifications using 4-12 classes to account for the possibility that LiDAR might enable identification of additional statistically distinct classes. We used hierarchical clustering to classify plot sites. Hierarchical clustering groups the most similar observations in a hierarchical fashion (Legendre and Legendre 1998). We used Euclidean distances and Ward's linkage method with the "hclust" function of the R statistical package (release 2.6.1) (R Development Core Team 2007) for this analysis. We used principal components analysis (PCA) to examine relationships between sites and classes using the "prcomp" function of the R statistical package (release 2.6.1) ( $\mathrm{R}$ Development Core Team 2007).

We further analyzed stand structure by the mixture of canopy structures present within the 9 ha sites. In previous work (Kane et al. 2010a, 2010b), we had defined structural classes for forest canopies at the $30 \mathrm{~m}$ scale. We assigned each of the one hundred $30 \mathrm{~m}$ grid cells within the 9 ha study sites to one of these classes identified in Kane et al. (2010b) using the Random Forest algorithm (Breiman 2001; Falkowski et al. 2009) in the yaImpute R statistical package (release 1.0) (Crookston and Finley 2008) using 500 classification trees.

\section{Spatial assessment of gap and patch arrangement: landscape analysis}

We analyzed the patch structure of our study sites to understand the composition and fragmentation of stands in terms of homogenous, matrix-patch, or patch mosaic landscapes (Wiens 1995). We assigned each $3 \mathrm{~m} \times 3 \mathrm{~m}$ canopy surface grid cell to upper, middle, or lower canopy strata. Canopy surface grid cells $<3 \mathrm{~m}$ in height were treated as a special case of canopy strata and identified as gaps. Patches and gaps were identified as contiguous grid cells in the same strata. The minimum size for a patch or gap was a single $3 \mathrm{~m} \times 3 \mathrm{~m}$ canopy grid cell. Because a small amount of foliage from higher strata might be present in the $9 \mathrm{~m}^{2}$ grid cell, this could lead to underreporting of the true area of gaps and lower strata.

Foliage in the upper third canopy layer was presumed to represent the original tree cohort, while heights $<3 \mathrm{~m}$ were assumed to represent a true gap. Foliage in the lower and middle third canopy layers was presumed to represent regrowth of different tree height, following partial disturbance, which is consistent with gap models and common stand development patterns. Distinguishing lower and middle canopy height layers allowed us to separate gap formation processes on a temporal scale.

We calculated the total area of each patch class, mean patch size in each of the four height layers, and the interspersion and juxtaposition index (IJI) metric using FRAGSTATS version 3.3 (McGarigal and Marks 1995). Unlike the more commonly used contagion index that measures interspersion at the grid cell level, IJI measures interspersion at the patch level. Values for IJI decrease as patch classes become more clustered and increase as patch classes become more uniformly interspersed. We also calculated the minimum number of patches within each site required to represent $80 \%$ and $90 \%$ of the canopy surface area as a measure of the dominance of large patches within each site.

\section{Spatial assessment of gap and patch arrangement: scales of variance}

We measured the scales at which patch structure varied using wavelet analysis. Wavelet analysis (Fortin and Dale 2005) identifies scales of structural variance within each site (Fig. 3) and has been used to study forest structure (Bradshaw and Spies 1992; Dale and Mah 1998; Brosofske et al. 1999; Keitt and Urban 2005; Kembel and Dale 2006). Stationarity in the data is not assumed in wavelet analysis; hence, it can be used to measure changing scales of variance. Variance reported at each scale is the sum of variance for all positions of a moving window at that scale. We tested one-dimensional (Haar, French top hat, Mexican hat, and Morlet) and two-dimensional (tall top hat, short top hat, boater, and sombrero) wavelet functions. The Mexican hat function best captured scales of variance in test patterns and transects taken from the study sites with minimum scale drift. All two-dimensional patterns tested performed poorly at identifying scales of variance and several exhibited continuously increasing variance with scale and no peaks.

Based on our preliminary analysis, we sampled variance across study sites using the Mexican hat wavelet function. To minimize the impact of possible anisotropy, wavelet analysis was performed for three equally spaced horizontal and 
Fig. 3. Sample canopy transects and resulting scales of variance measured with the Mexican hat wavelet for sample transects from each structural class (1-6) identified in this study. Three test patterns based on repeating profiles of one mature tree are shown for comparison. Multimodal variance patterns reflect multiple scales of structure within the canopy. Wavelets computed from smoothed $1.5 \mathrm{~m}$ canopy surface models calculated from LiDAR data. Example transects from each class identified in this study are from the 100th (of 200) row of the sites shown in Fig. 9.
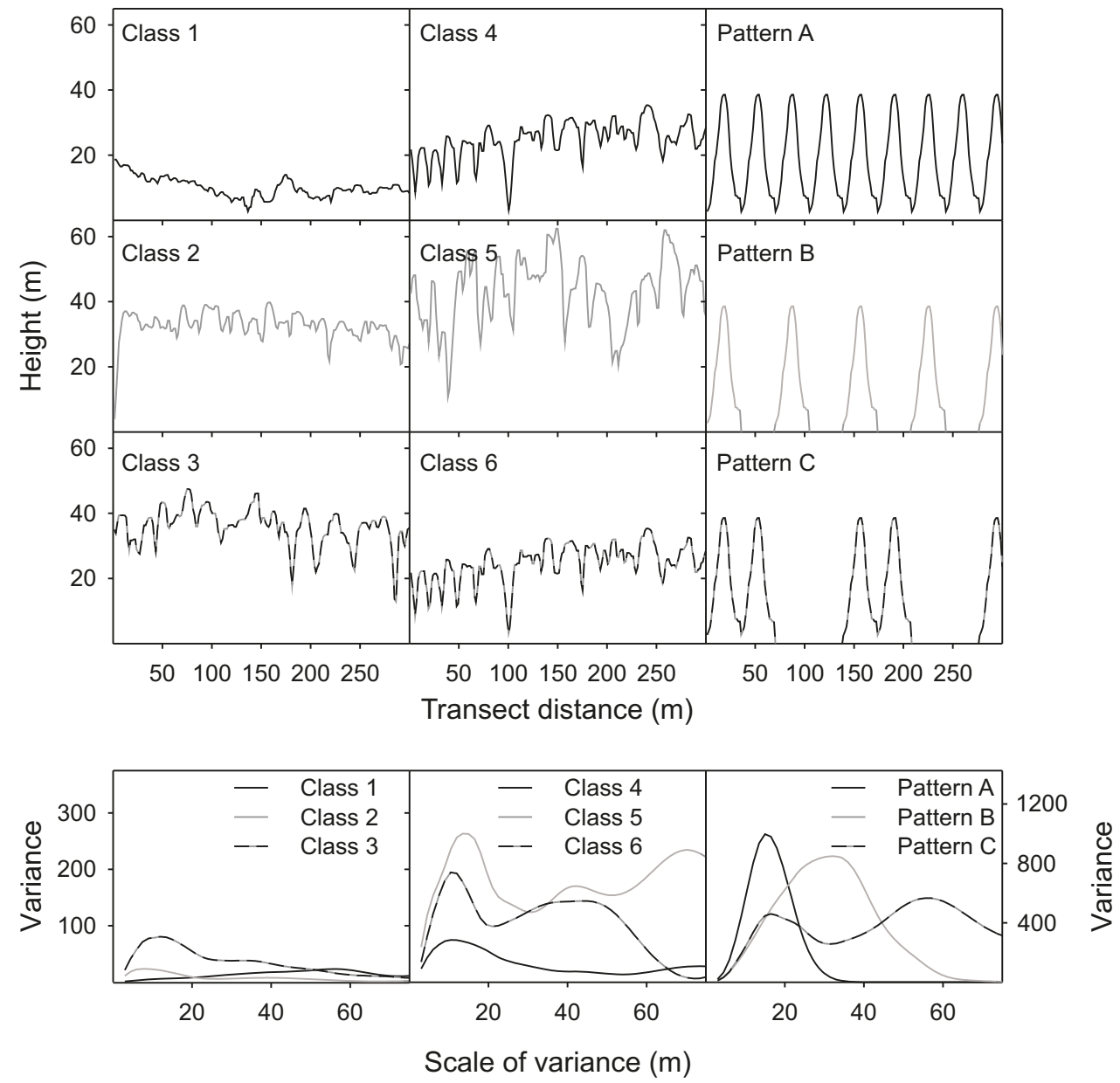

three equally spaced vertical transects in each site (Kembel and Dale 2006) using the smoothed $1.5 \mathrm{~m}$ CSMs. This resulted in placement of transects at 75, 150, and $225 \mathrm{~m}$ (rows and columns 50, 100, and 150) for each 9 ha study site. We then calculated and reported the mean variance for each scale from all six transects. Because the Mexican hat wavelet compares four adjacent windows of data at a time, the maximum scale that it can examine for variance is one quarter the length of a transect. For the 9 ha sites, this maximum was $75 \mathrm{~m}$, and for the 64 ha sites, this maximum was $200 \mathrm{~m}$. We based our primary analysis of spatial variance on results from the ninety-five 9 ha study sites and extrapolated larger scale trends from the five 64 ha study sites. Wavelet statistics were calculated with the PASSaGE 2 program (http://www.passagesoftware.net) (Rosenberg and Anderson 2011).

\section{Results}

\section{Classes of stand structure}

We used the results of the hierarchical cluster analysis to identify and interpret six classes of stand structure for the ninety-five 9 ha sites, which maintained statistical separation between classes (hierarchical cluster height $>10$ ) (Fig. 4; Table 1). Structural classes from Kane et al. (2010b) were assigned to each of the one hundred $30 \mathrm{~m}$ grid cells within the 9 ha study sites with an out-of-bag error estimate (Breiman 2001) of $5.3 \%$. One or two structural classes from Kane et al. $(2010 b)$ were found to dominate each 9 ha structural class identified in this present study (Fig. 5). Class identification numbers were assigned to each 9 ha study site so that higher class numbers reflected conditions associated with greater structural complexity such as greater rumple, lower canopy closure, higher patch counts, and higher wavelet variance (Fig. 6). While class assignments were based only on LiDAR metrics, the LiDAR, landscape, and wavelet variance metrics were frequently correlated (Table 2).

The PCA using the mean and standard deviation of the three LiDAR metrics also differentiated among structural classes (Fig. 7). Mean and standard deviation of rumple were associated with the first PCA axis (55.5\% of variation). Mean 95th percentile height and canopy closure (mean and standard deviation) explained approximately equal variance and were associated with the second PCA axis $(26.3 \%$ of variation). Standard deviation of 95th percentile height had the 
Fig. 4. Dendrogram showing six classes identified from hierarchical cluster analysis based on mean and standard deviation for the 95th percentile height, rumple, and canopy closure LiDAR metrics calculated for 100 grid cells per 9 ha site. Numbers below the dendrogram identify the canopy structural classes; percent values of primary (P) and secondary (S) sites within each class are shown. Height shows statistical distance between classes.

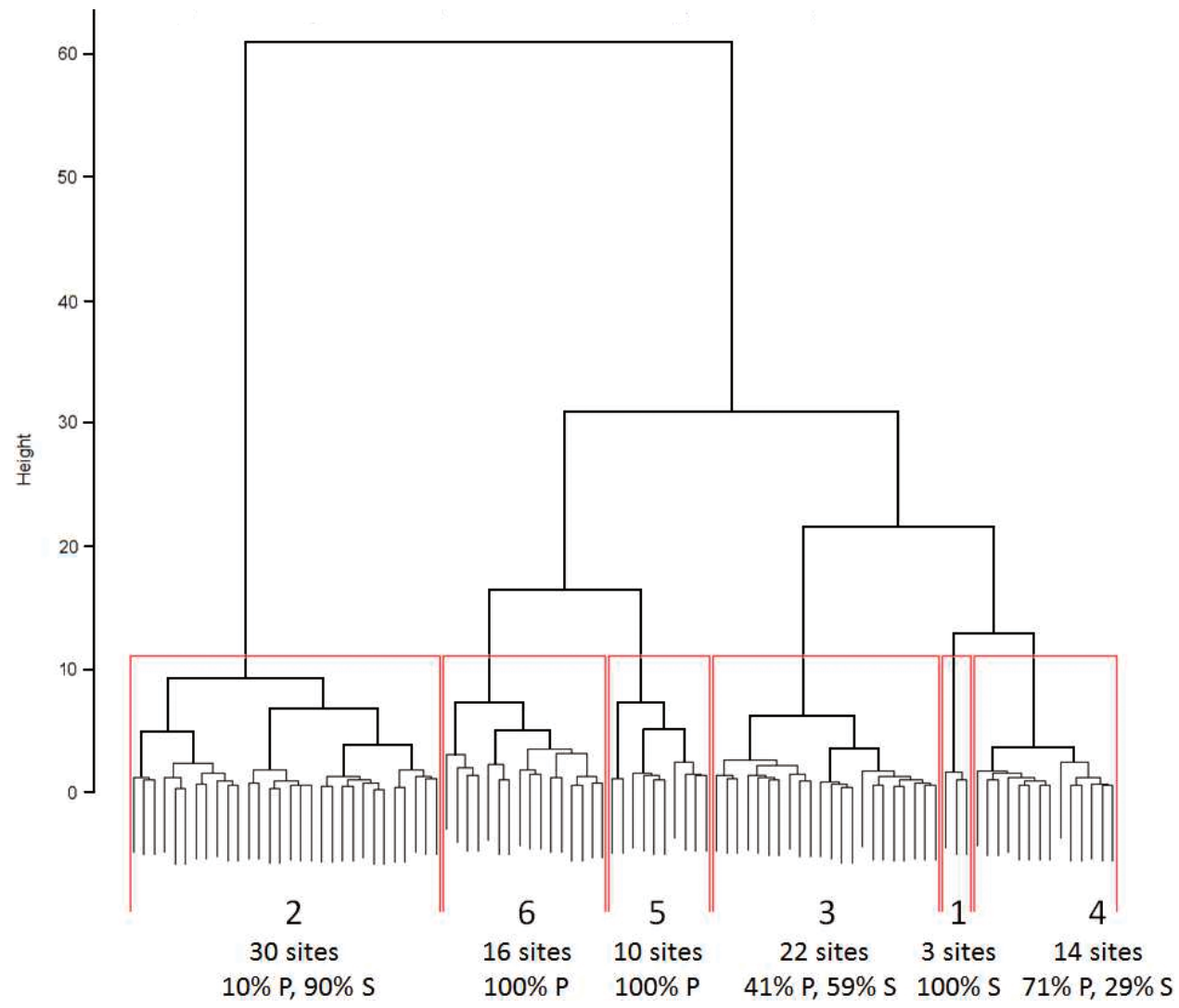

Table 1. Characteristics of structural canopy classes identified in this study.

\begin{tabular}{|c|c|c|}
\hline Class & Descriptive name; development stage & Defining characteristics \\
\hline 1 & Short, open canopies; stand establishment & $\begin{array}{l}\text { Short, open canopies with considerable horizontal patchiness; } \\
\text { youngest sites }\end{array}$ \\
\hline 2 & $\begin{array}{l}\text { Homogenous canopies; competitive exclu- } \\
\text { sion }\end{array}$ & $\begin{array}{l}\text { Few gaps and patches and little structural complexity at local and } \\
\text { patch scales }\end{array}$ \\
\hline 3 & Low structural complexity; maturation & $\begin{array}{l}\text { Increased canopy structural complexity compared with class } 2 \text { at both } \\
\text { local and patch scales }\end{array}$ \\
\hline 4 & $\begin{array}{l}\text { Fine-scale heterogeneity; high-elevation } \\
\text { structural complexity }\end{array}$ & $\begin{array}{l}\text { Small patches and gaps interrupting dominant canopy with moderate } \\
\text { structural complexity at local and patch scales and lower mean } \\
\text { canopy closure than all classes except class } 6 \text {; lower mean canopy } \\
\text { heights than all classes except class } 1\end{array}$ \\
\hline 5 and 6 & $\begin{array}{l}\text { Heterogeneity at all scales; shifting patch } \\
\text { mosaics }\end{array}$ & $\begin{array}{l}\text { Numerous gaps and canopy patches with high variance at all scales } \\
\text { indicating nonrepeating patch patterns; strong variations in canopy } \\
\text { height reflected by high rumple values; class } 6 \text { differed from class } \\
5 \text { with shorter canopies, greater canopy openness, and high patch } \\
\text { count per hectare }\end{array}$ \\
\hline
\end{tabular}

Note: Stand development stages with equivalent canopy characteristics are given. Local $(<30 \mathrm{~m})$ scale heterogeneity measured by rumple values; patch scale heterogeneity measured by wavelet variance.

least explanatory power and was associated with the third PCA axis (18.2\% of variation).

Structural classes were associated with age ranges and elevation (Fig. 8). Younger secondary forest sites were predominately in classes 1-3 with older secondary sites predominately in either class 3 or 4 . Primary forest sites were predominately in classes 4-6 with only four primary sites in class 2 . Only class 3 had large numbers of both primary and secondary sites.

Relationships between secondary sites and elevation reflected the harvest history that progressed from lower to higher elevations over approximately 90 years. The youngest secondary sites (class 1) were found at higher elevations and the oldest secondary sites (classes 3 and 4) were found at the 
Fig. 5. Structural composition of the 9 ha study sites used in this study. Kane et al. (2010b) defined structural classes for 0.09 ha sites within the study area used in this study, and the classes from Kane et al. (2010b) were assigned to each of the one hundred $30 \mathrm{~m}(0.09 \mathrm{ha})$ grid cells within each 9 ha study site. Distinguishing characteristics of the classes identified by Kane et al. (2010b) were (numbers in parentheses identify class numbers used in Kane et al. (2010b)) pre-canopy closure ( 1 and 2$)$ mean 95th percentile height $\leq 12.5 \mathrm{~m}$ and mean canopy closure $\leq 0.76$, dense, low-complexity ( 3 and 4 ) mean rumple $\leq 1.8$ and mean canopy closure $\geq 0.97$, moderate-complexity ( 5 and 6 ) mean rumple 2.4-2.7 and canopy closure 0.87-0.93, and high-complexity ( 7 and 8 ) mean rumple $\geq 3.3$ and canopy closure $\leq 0.86$. Each 0.09 ha structural class reported here corresponded to two structural types in Kane et al. (2010b) that differed primarily in 95th percentile height.

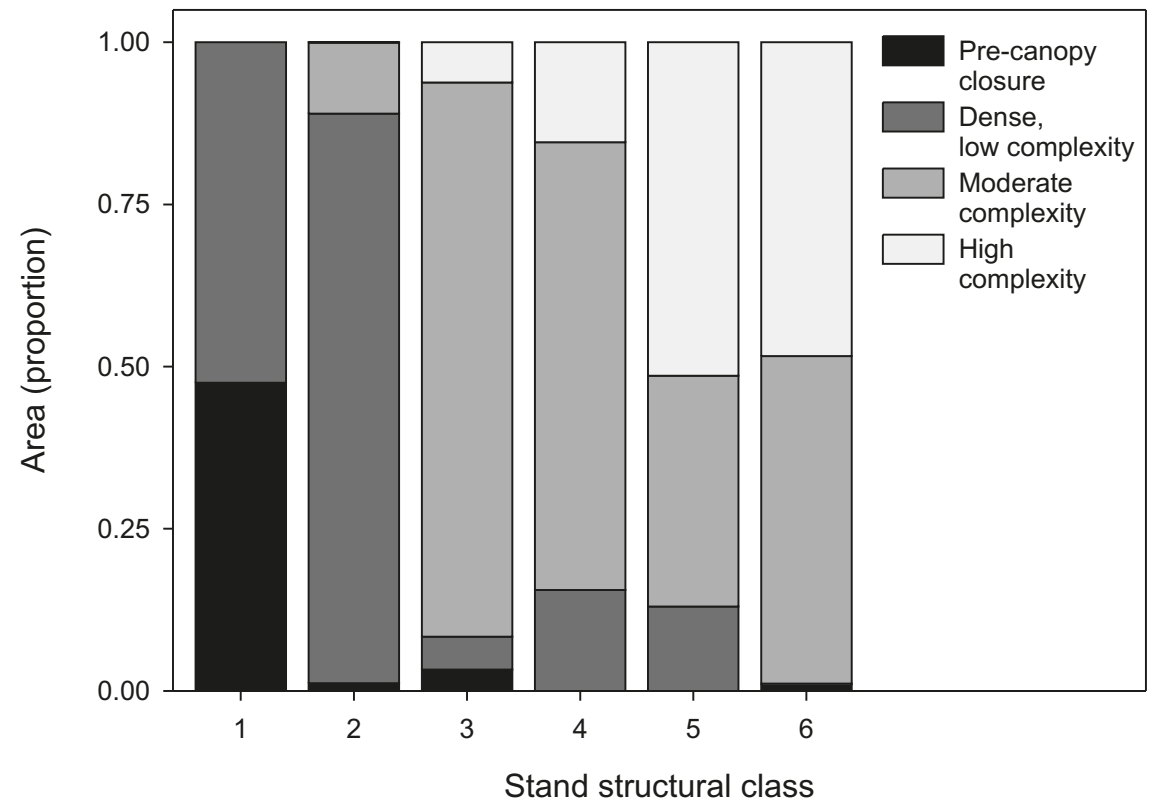

lower elevations. Primary forest sites, on the other hand, did not show a clear relationship between class and elevation. Class 5 primary sites could be statistically distinguished from class 4 and 6 sites based on elevation $(P=0.05)$, but classes 4 and 6 could not be distinguished.

\section{Spatial assessment of gap and patch arrangement: landscape analysis}

Sites in all structural classes were found to be composed of multiple patches identified through differences in canopy surface height (Fig. 9) with most gaps $<100 \mathrm{~m}^{2}$. The relationship between the frequency and size of gaps followed a power law with exponent of $-2.06\left(R^{2}=0.98\right)$ (Fig. 10). Patch count in the middle, lower third, and gap layers generally increased from class $2\left(20.2\right.$ patches $\left.\cdot h^{-1}\right)$ to class 6 (90.0 patches $\cdot$ ha $^{-1}$ ) (Fig. 11).

For classes 2-4, single patches on average accounted for $>80 \%$ of the canopy (Fig. 6); for other classes, 2.4-4 patches on average were needed to cover the same area. To cover $90 \%$ of the site area, classes 2 and 3 required less than four patches on average, while classes 1,3 , and 5 required 33-48 patches and class 6 required 220 patches. Eighty-five percent of the sites had canopies where upper third canopy patches comprised more than half the canopy area. The remaining canopy area was dominated by middle third canopy patches, and lower third patches and gaps covered only a small percentage of the area. Only for class 6 did the combined area of lower canopy and gap patches constitute more than $10 \%$ of the site area.

Mean IJI was 20 for class 2 and 81 for class 6 and these two classes were statistically distinct from other classes and each other (Tukey HSD, $P \leq 0.05$ ). IJI values for classes 1 ,
3, 4, and 5 averaged 58 and were not statistically distinct from one another.

\section{Spatial assessment of gap and patch arrangement: scales of variance}

Variance was greatest at all sites at the $10-15 \mathrm{~m}$ scales. (Fig. 12). Variance then declined until scales of 20-30 m, after which variance typically either plateaued or showed a gradual decrease but less frequently showed a rapid decrease or gradual increase. These patterns were observed for scales of up to $75 \mathrm{~m}$ (9 ha plots) and for scales of up to $200 \mathrm{~m}$ (64 ha plots). Variance at scales $>30 \mathrm{~m}$ in the 9 ha sites was highly correlated with variance at scales $\leq 30 \mathrm{~m}(R=0.88)$ and was a substantial fraction of the variance at scales $\leq 30 \mathrm{~m}$. In the 64 ha sites, variance had reached low levels in a primary and secondary site by $50 \mathrm{~m}$ and by $150 \mathrm{~m}$ at a second pair of primary and secondary sites. In the 680 year old site, variance remained high at all scales.

\section{Discussion}

\section{Classes of stand structure}

The physical structure of a forest has many components but is often described by the size and spatial distribution of trees and by the horizontal and vertical distribution of their foliage (Spies 1998; Van Pelt and Nadkarni 2004; McElhinny et al. 2005). These components often change as stands mature as do other aspects of forest structure and diversity that are directly or indirectly related to the size and spatial distribution of trees such as the abundance of coarse woody debris and dead trees and diversity of the understory (Franklin and Spies 1991; Lindenmayer and Franklin 2002). No single field 
Fig. 6. Median and ranges for 95th percentile height, rumple (canopy rugosity), and closure LiDAR metrics, patch count metrics, and wavelet variance structural complexity metrics by structural class (1-6) identified in this study. The line within each box shows the median and the upper and lower box boundaries show the 75th and 25th percentiles, respectively. The error bars above and below the box show the 90 th and 10th percentiles. Circles show outliers. Numbers within parentheses identify statistically indistinguishable groups of classes for each metric (Tukey's HSD, $P \leq 0.05$ ).

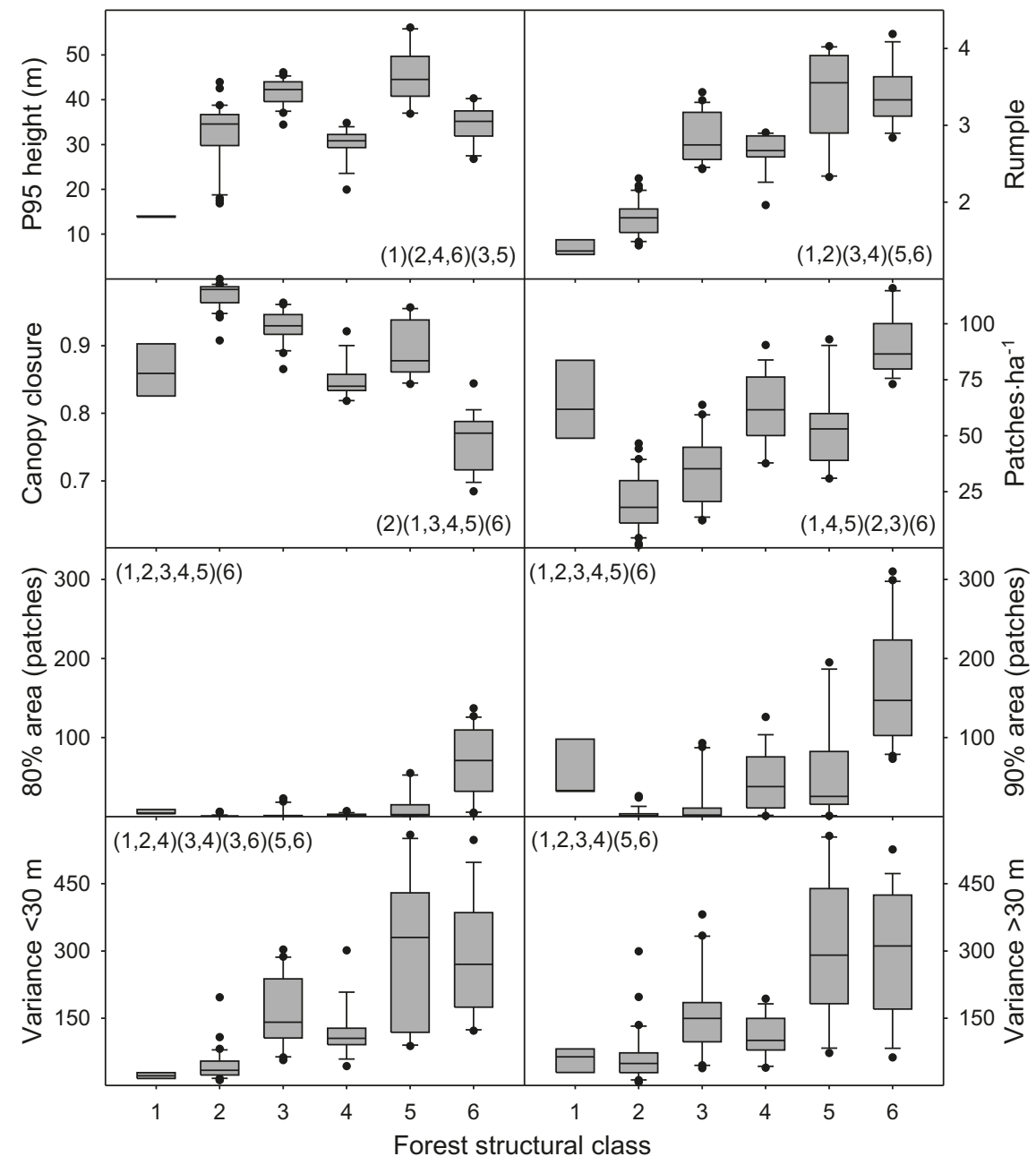

or LiDAR measurement captures the state of a stand's structural development. Instead, studying patterns of development requires examining relative changes in suites of metrics, often using multivariate analyses (Spies and Franklin 1991; Larson et al. 2008). For example, four field variables (mean diameter at breast height, standard deviation of diameter at breast height, tree density, and density of trees with diameter at breast height $>100 \mathrm{~cm}$ ) are strongly correlated with the structural stage in Pacific Northwest forests (Spies and Franklin 1991) and can be used to estimate the degree to which a stand has progressed toward old-growth characteristics (Acker et al. 1998). Kane et al. (2010a) identified a suite of three LiDAR metrics, 95th percentile height, canopy density, and rumple, as having equivalent explanatory power and strong correlation with this suite of field metrics.

We used these three LiDAR metrics to identify classes of forest structure both at the 0.09 ha (using Kane et al (2010b) classes) and the 9 ha (using classes identified in this study) scales. We found that the Kane et al. (2010b) canopy structural classes were not unique to any class identified at the 9 ha scale (Fig. 6). Rather, the 9 ha classes were differenti- ated based on the proportion of Kane et al. (2010b) structural classes.

For the 9 ha study sites, rumple was the strongest differentiator among structural classes and canopy closure was the second strongest (Fig. 7). Rumple values increase when trees are removed from the canopy through disturbance mortality, but values gradually decrease as gaps are filled, whether through regeneration or from the adjacent canopy (Birnbaum 2001; Ishii et al. 2004). Canopy closure decreases through the same processes, although subsequent regeneration and branch growth moderate this trend. The 95th percentile height increases with age, constrained by species present, site productivity, and trunk breakage. The correlation between rumple and wavelet variance at scales $<30 \mathrm{~m}(R=$ $0.86)$, rumple and patch diversity as measured by IJI $(R=$ 0.83 ), and SD rumple and wavelet variance at scales $>30 \mathrm{~m}$ $(R=0.67)$ (Table 2$)$ suggests that rumple integrates height variations across multiple scales and is sensitive to the diversity of patch structure. Similarly, the correlation between canopy closure and gap area $(R=0.88)$ suggests that the LiDAR closure metric primarily measured gap presence. 


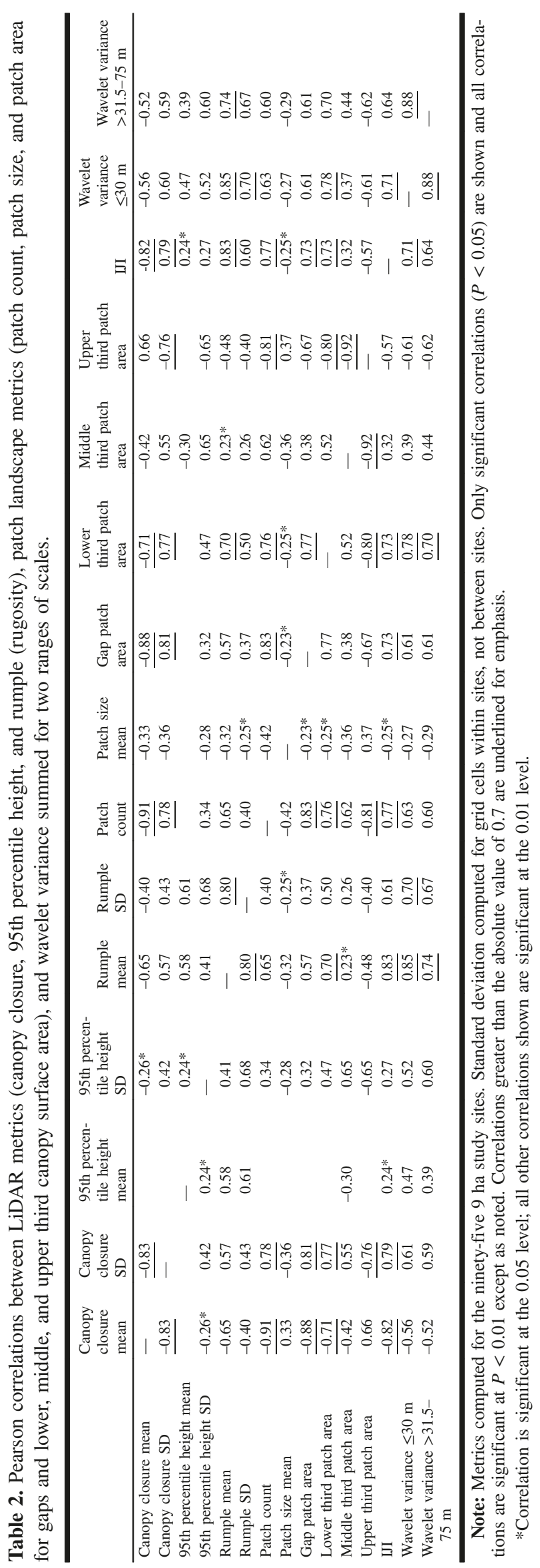

\section{Spatial assessment of gap and patch arrangement: landscape analysis}

Patches are areas within which structure is similar and where structure differs from the surrounding forest (Forman 1995). Previous work has shown that airborne LiDAR data can be used to identify patches within canopies (Koukoulas and Blackburn 2004; Vepakomma et al. 2008; Vehmas et al. 2011). These studies have included analysis of gap structure across multiple tropical forests (Kellner and Asner 2009) and rates of gap formation and closure (Vepakomma et al. 2011).

Field-based gap studies generally identify two patch types: full gaps and the surrounding matrix of closed canopy forest (Runkle 1982). Some studies used height cutoffs of 15-20 m to define gaps to include patches with young regeneration (Runkle 1992). Using LiDAR's ability to differentiate among canopy heights (which is difficult to do in ground-based studies), we extended this latter approach to identify three patch types relative to the maximum CSM height for each site in addition to full gaps. We interpreted upper layer patches as undisturbed or minimally disturbed canopy representing the initial tree cohort, middle layer patches as advanced regeneration resulting from past disturbances, and lower layer and gap patches as sites of recent disturbance that differed in the height of regeneration. These interpretations are consistent with common stand development models. On the other hand, interpretation of these strata must be considered in the context of forest age and species composition. For example, middle layer patches can also represent areas with tree top breakage, which was widespread only in the two 680 year old sites.

Gap patches covered a small fraction of all primary forest sites (3.2\%) (Fig. 11) in our study, while other researchers have reported gap areas of 13\%-18\% for primary forests in the Pacific Northwest (Spies et al. 1990; Lertzman et al. 1996). The lower gap area in our study could be related to our methods for identifying a gap patch in which each $9 \mathrm{~m}^{2}$ square CSM could have no LiDAR return at $>3 \mathrm{~m}$. The LiDAR canopy closure metric may be a better measure of gap area over larger areas than identifying gaps from the CSM. The area that this LiDAR metric detected as open canopy for primary sites $(15.2 \%)$ was similar to the area in gaps reported by previous studies. CSM height measurements and canopy closure, however, are complimentary measures. CSMs measure the height of the canopy surface and can be computed with a single LiDAR return per grid cell. Canopy closure does not measure the height at which canopy material is found and is computed as a proportion requiring calculation over larger grid cells representing many returns.

Previous work had reported negative exponential distributions of gap sizes for a wide range of forest types subject to chronic small-scale disturbances (Kellner and Asner 2009). We found a similar distribution of gap sizes (Fig. 10). This was consistent with the observations that gap dynamics in our study region predominately results from chronic, smallscale disturbances that each cause the death of one to a handful of trees (Lertzman et al. 1996; Lutz and Halpern 2006). It should be noted that the distribution of gap sizes likely does not strictly record the areal extent of each event, since gaps frequently grow as the result of sequential disturbances (Lertzman et al. 1996). Smaller gaps are also likely to fill in more quickly than larger gaps. Wind disturbances covering 
Fig. 7. Principal components analysis of ninty-five 9 ha study sites using mean and standard deviation of 95th percentile height, rumple, and closure LiDAR metrics. Sites are identified by structural class (1-6) identified in this study and a suffix indicating primary (P) or secondary (S) forest. The two 680 year old sites are designated with an OG suffix. Asterisks indicate sites from each class selected to illustrate differences between classes in Figs. 3, 9, and 12.

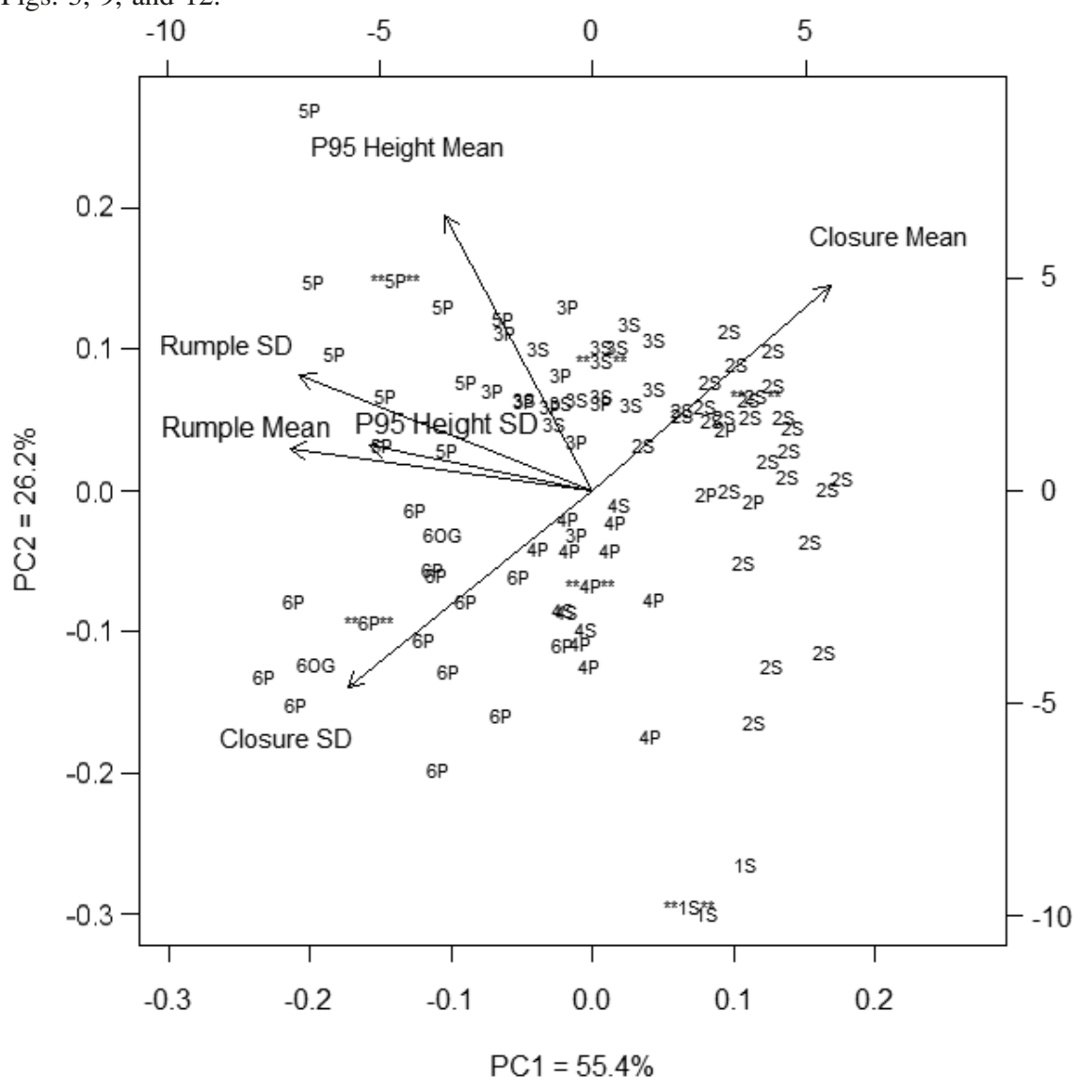

Fig. 8. Median and distribution of study sites grouped by structural classes (1-6) identified in this study and primary (P) $>220$ years old and secondary $(\mathrm{S}) \leq 91$ years old age ranges. Elevation ranges for forest zones are shown. The line within each box shows the median and the upper and lower box boundaries show the 75th and 25th percentiles, respectively. The error bars above and below the box show the 90 th and 10th percentiles. Circles show outliers. Numbers within parentheses show statistically significant groupings of classes (Tukey's HSD $P \leq$ 0.05). Class 6P was distinct from class $4 \mathrm{P}$ based on elevation at $P=0.05$.

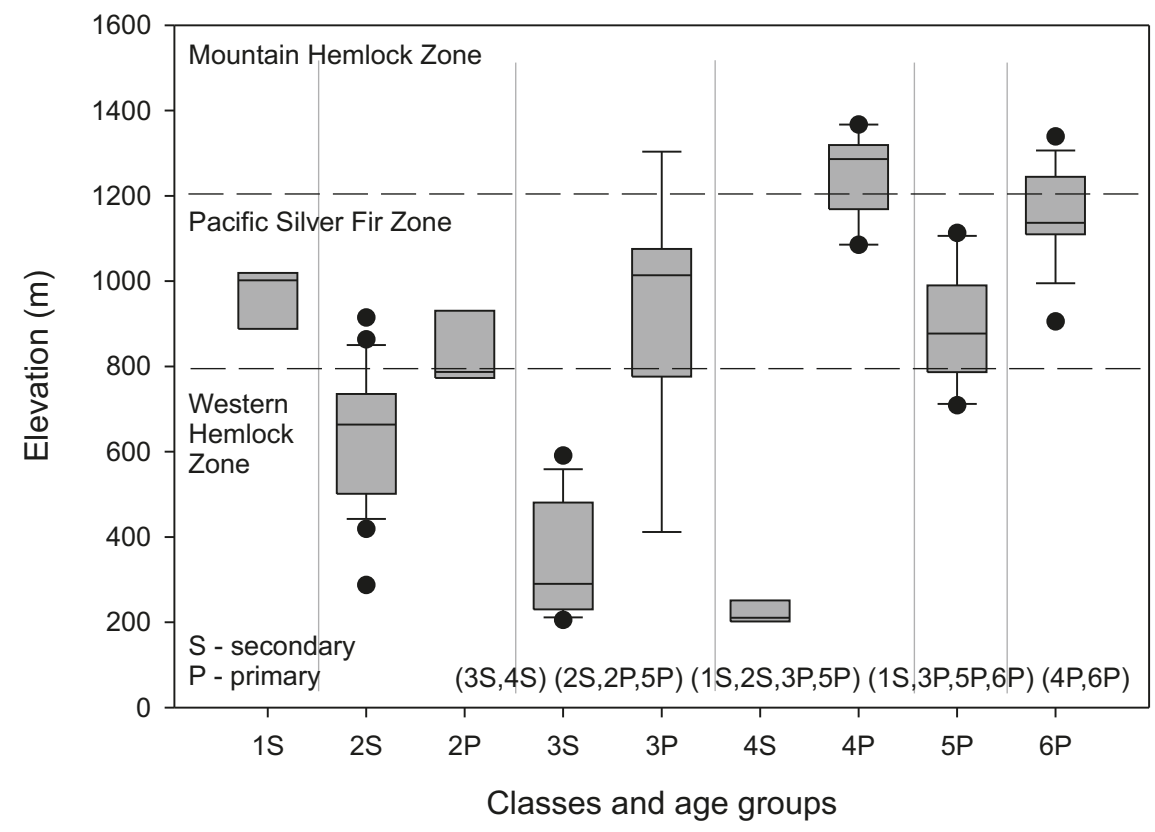


Fig. 9. Canopy maps of selected study sites based on the $3 \mathrm{~m}$ canopy surface model created from LiDAR data. Grid cells were assigned to gaps (maximum height $<3 \mathrm{~m}$ ) or to canopy layers relative to each site's 95th percentile canopy height. These example sites were also used for Figs. 3 and 12 and are identified in Fig. 7.

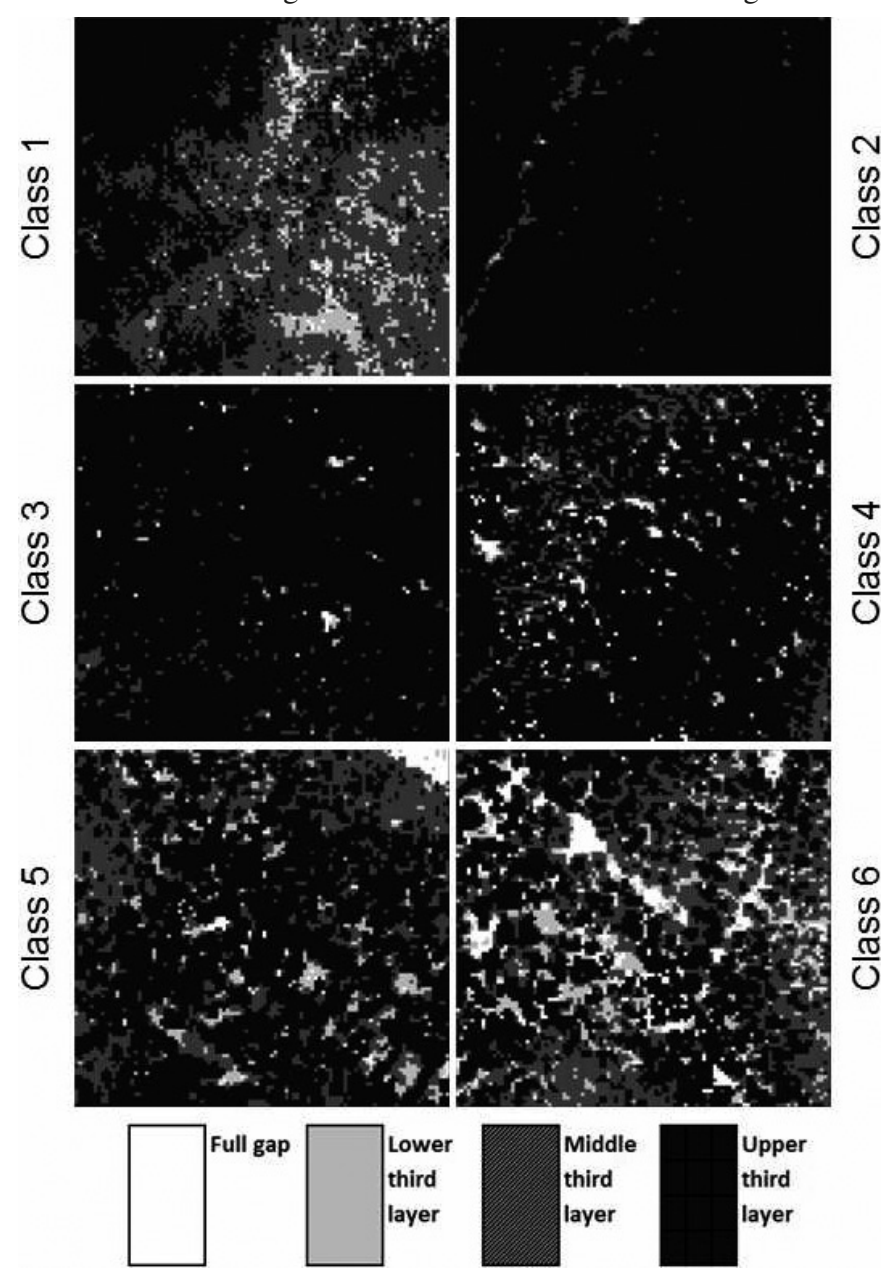

Fig. 10. Frequency distribution of gap patch sizes from all ninetyfive 9 ha study sites on $\log -\log$ scales. Minimum gap size measured was $9 \mathrm{~m}^{2}$. Negative exponential distribution with exponent of -2.06 (adjusted $R^{2}=0.98$ ) reflects the frequency of small disturbances and rarity of larger disturbances.

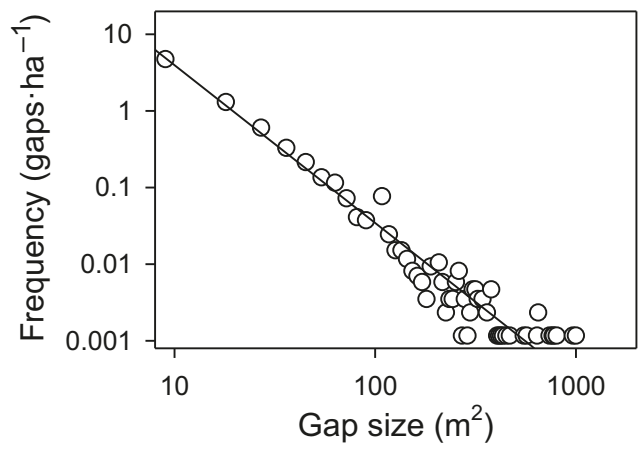

several hectares have been recorded within our study region (Sinton et al. 2000). However, these large gap-creation events appear to be rare, on the order of every few centuries at any single location (Sinton et al. 2000; Winter et al. 2002). The rarity of gaps $>500 \mathrm{~m}^{2}$ in our data set (Fig. 10) supports this conclusion.

Fine-scale patch mosaics are a defining attribute of oldgrowth forests (Shugart 1984; Spies 1997; Franklin and Van Pelt 2004). Hence, quantitative differences between classes can be used to differentiate canopy structure as homogenous, matrix-patch, or patch mosaic landscapes (sensu Wiens 1995). We first considered IJI values and the number of patches required to cover $80 \%$ and $90 \%$ of site area (Fig. 6) to assign our classes to Wiens' (1995) landscape types. Using these criteria, classes 2 and 3 were best described as homogenous canopies, classes 1, 4, and 5 as matrix-patch structure, and only class 6 as a patch mosaic (Fig. 11). If rumple and wavelet values are also considered, class 5 also would be considered a patch mosaic with values similar to class 6 . This latter division of sites reflects the division of sites reported by hierarchical clustering (Fig. 4) based on LiDAR metrics. However, it should be kept in mind that patch structure commonly varied across sites, and many sites were mixtures of these Wiens (1995) patch structures.

\section{Spatial assessment of gap and patch arrangement: scales} of variance

Wavelet variance for all sites was highest at the $10-15 \mathrm{~m}$ scales (Figs. 3 and 12), consistent with differences in height among small clusters of trees or trees and adjacent small gaps. Bradshaw and Spies (1992) reported similar patterns of variance for gap structure in 43-275 year old stands in our study region.

Smith and Urban (1988) predicted rapidly diminishing heterogeneity beyond the scale of tree clusters and small gaps based on their modeling. They found that while the actual development trajectory of an individual plot (0.01 ha) within their simulated 9 ha plot could not be predicted, variability between aggregates of plots at patch scales $(>0.09-0.16$ ha) was minimal. In their modeling, Smith and Urban (1988) applied the same stochastic mortality process across the entire model area. As a result, their modeling suggested uniformly distributed processes producing repeating patterns of tree clusters, gaps, and regeneration patches across stands.

We found that many sites in our study had high variance at scales of up to $75 \mathrm{~m}$ (9 ha sites) or 100-200 m (64 ha sites) (Figs. 3 and 12), suggesting that disturbance processes were not uniformly distributed across our study areas in space or time. The high variability may be the interaction of stochastic events and the geomorphic template. For example, the locations of wind bursts may be random, but the spatial pattern of prevalent high winds is influenced by topography. The interaction of trees with the disturbance agent, on the other hand, is affected by edaphic conditions (rooting depth) and the unpredictable distribution of root rot. The combination of factors will lead to uneven distribution of disturbance effects, as indicated by high structural variance at larger spatial scales in our study sites.

Zenner (2005) similarly found that variance within 1 ha plots peaked at scales of $10-15 \mathrm{~m}$ and plateaued or entered a gentle decline at scales of $31.6 \mathrm{~m}$. In a 3.3 ha site, Winter et al. (2002) found three major disturbance events at $>200$ year intervals, resulting in shifting regeneration and release of subcanopy trees. They noted that heterogeneous dis- 
Fig. 11. Number of patches (left panels) and cumulative area (right panels) assigned to gaps and canopy layers in each structural class (1-6) identified in this study. The line within each box shows the median and the upper and lower box boundaries show the 75th and 25th percentiles, respectively. The error bars above and below the box show the 90th and 10th percentiles. Circles show outliers. Numbers within parentheses show groups of classes that are statistically different (Tukey's HSD $P \leq 0.05$ ).

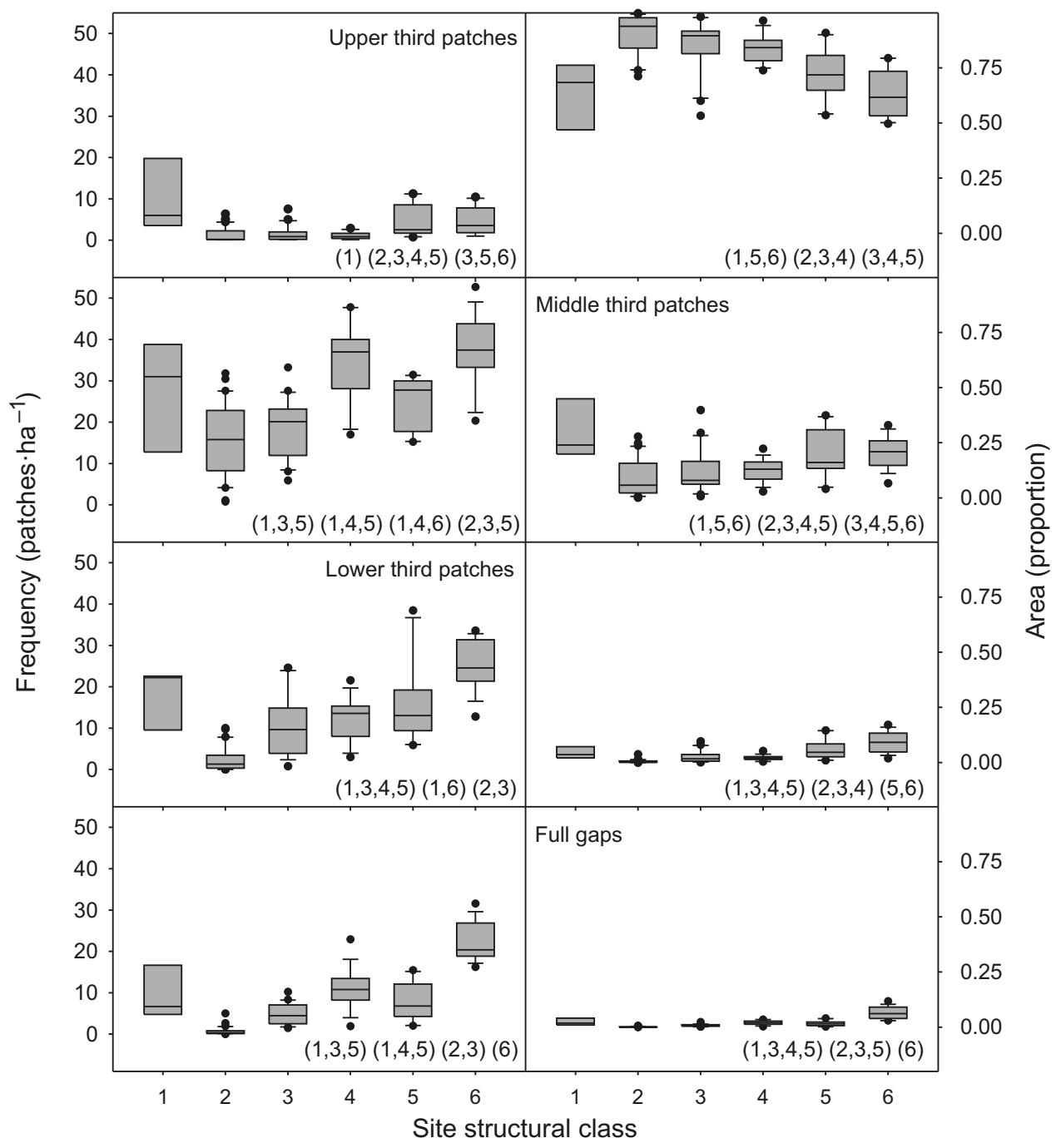

tribution of disturbance should lead to the development of patch structure. This high variance at larger scales appears to be an emergent property that cannot be understood as a simple extrapolation of processes observed at smaller spatial scales.

\section{Patterns across the chronosequence}

Researchers have developed models of forest development for long-lived forests that relate aspects of stand structure, including patch structure, to stand development (e.g., Franklin et al. 2002). Our previous work related canopy structure at the plot scale $(0.09 \mathrm{ha})$ to commonly recognized stages of forest development (Kane et al. 2010a). When we considered the 9500 grid cells (each also 0.09 ha) in our 9 ha study sites as separate samples (Fig. 5), they covered the same range of structural conditions found by Kane et al. (2010a). This study's quantitative delineation of patch structure extends our understanding of forest development to new scales of study. We were able to relate the patch structure in our 9 ha study sites to forest development stages (Oliver and Larson
1996; Spies 1997; Franklin et al. 2002) (Figs. 6 and 11) as follows. (i) Establishment (class 1): recently established sites have short canopy heights and considerable horizontal patchiness. (ii) Biomass accumulation/competitive exclusion (class 2): after canopy closure, stands have homogenous canopies with few if any gaps and little to no patch structure. (iii) Transition/maturation (class 3): disturbance replaces competition as the primary mortality agent and gaps begin to break up the canopy and create patch structure. (iv) Shifting patch mosaics (classes 5 and 6): gaps become common as disturbances remove individual and small clusters of trees leading to shifting mosaics of patches of different ages and structural development; strong variations in canopy height are common as vertical diversification results as regeneration fills older gaps and trees in the initial cohort reach their maximum height.

Our results suggest that forest types may influence patch structure in primary forests. For example, while classes 4 and 6 could not be distinguished statistically based on elevation, class 4 primary sites had the highest mean elevation 
Fig. 12. Wavelet (Mexican hat) variance for one site from each class (1-6) identified in this study and for five 64 ha sites. (Sites for each class were also used for Figs. 3 and 9.) Because reported wavelet variance reflects the absolute height of trees in a stand and length of transect, both measured and relative variances normalized to measured variance at the $3 \mathrm{~m}$ scale are shown. Variance reported at a particular scale is the sum of variance for all positions of a moving window at that scale for the length of that transect ( $300 \mathrm{~m}$ for 9 ha sites and $800 \mathrm{~m}$ for 64 ha sites). Variance reported for each site was the mean variance at each scale for three equally spaced vertical and three equally spaced horizontal transects.

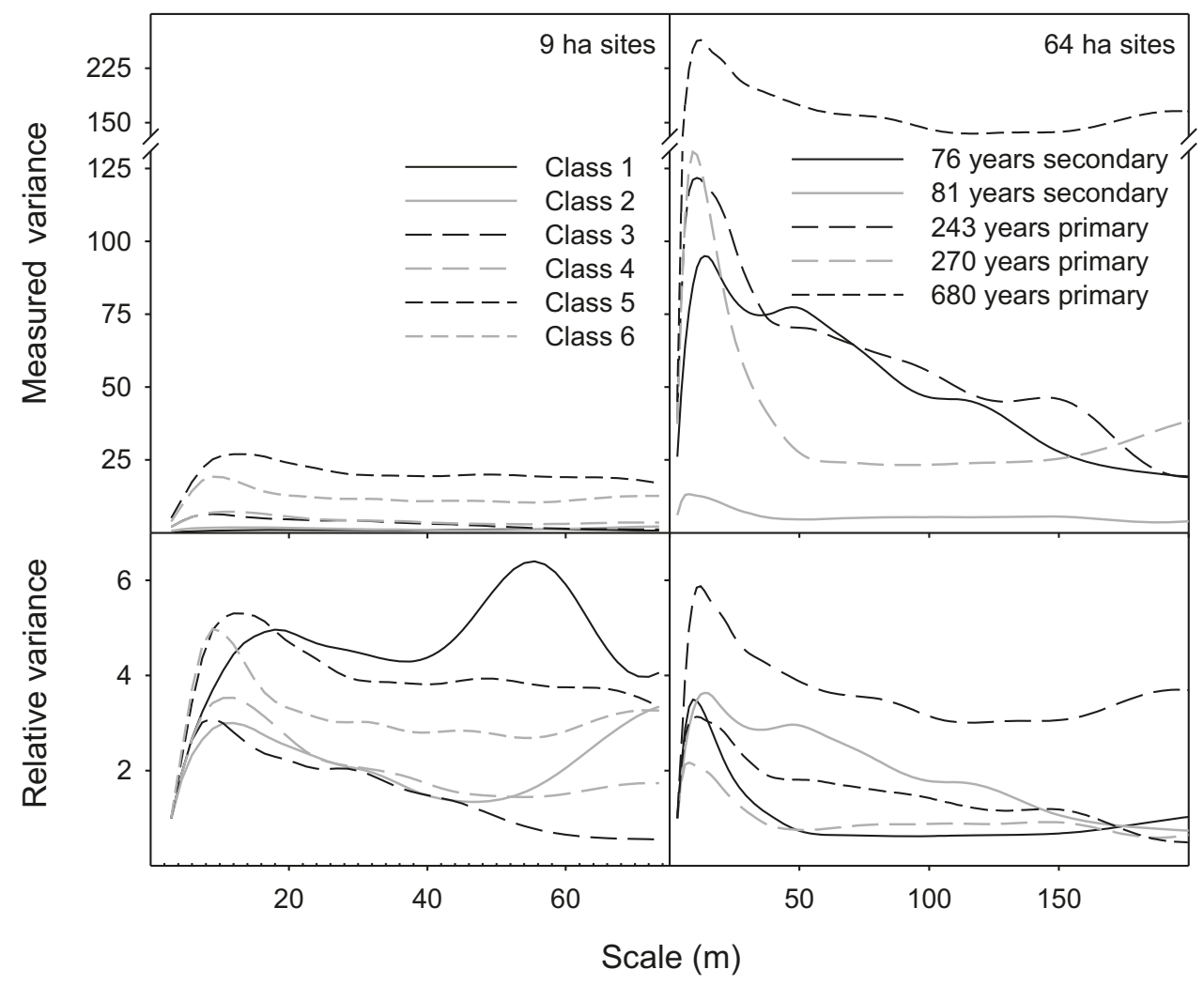

(1252 m), consistent with the Mountain Hemlock Zone. Primary forests in this zone are characterized by low heights, dense canopies, and small gaps that result from deaths of individual trees from disturbance (Parish and Antos 2006). This could account for class 4's characteristics that were similar to both the transition/maturation and patch mosaics stages of forest development.

Patch mosaics in our region have been hypothesized to be associated with a distinct stage of forest development that typically develops 300 years after stand initiation (Franklin et al. 2002; Van Pelt and Nadkarni 2004). Our results generally fit these expectations, with class 1 composed of young sites $<54$ years old $($ mean $=44$ ), class $290 \%$ composed of sites < 91 years old, and classes 4-6 90\% composed of primary sites (Fig. 8). However, some older stands failed to develop the complex patch structure (primary stands in class 2), while a few young stands $<100$ years old had developed complex patch structures (secondary sites in class 4 ).

The class 3 sites in our study appear to have been stands in transition between low-complexity stands dominated by a single patch to stands with patch mosaics. This class had numerous sites both $<91$ years old and $>220$ years old, suggesting either that the age at which stands begin the transition can vary by over a century or that the duration of this phase can last for more than a century.

The time required for patch structural development appears to be highly variable and is likely uniquely linked to each site's establishment history, site productivity, tree species composition, and the experienced disturbance regime. Frelich and Reich's (1995) study of patch development across 57 years supports this hypothesis. Young stands initially were typically matrices of multihectare patches that over 57 years might remain relatively unchanged or become finescale mixtures of small patches. The stand development path experienced depended on the random occurrence and distribution of disturbances. Zenner (2004) also found that the relationship of site age with structural complexity depended on disturbance history. He found that stands hundreds of years old could have widely differing structural complexities, with disturbance history rather than age being the primary predictor of structural complexity.

\section{Implications for forest management}

The patterns of spatial heterogeneity that we observed have implications for both ecologically based forestry and forest restoration. Structural heterogeneity is connected with important ecological functions (Shugart et al. 2010) such as habitat, productivity, and biodiversity, but little guidance is available on the scales at which this structural variability in forest canopies occurs. Our results clearly indicate the range of spatial heterogeneity and emerging patterns in forests of the Pacific Northwest. Where managers seek to manage forests within the range of natural variability and disturbance regime (North and Keeton 2008), an age-class forest at the 
scale of many hectares may not have a natural analog in forests where small-scale disturbances predominantly determine stand structural development. The variability that we observed at scales up to multiple hectares would better be achieved by managing forest stands in a group-like pattern, creating the matrix-patch structure common in younger stands. Where on the other hand forest mangers aim to restore ecosystem functions by establishing structural variability similar to old-growth forests, large-scale structural heterogeneity at the hectare scale should be a primary objective. We observed the establishment of small-scale heterogeneity through disturbances in young second-growth forests (see also Lutz and Halpern 2006), but the development of larger scale variability, in particular patch mosaic structures, appeared to be a pattern unique to old forests that was missing in second-growth stands. Finally, management that retains small-scale heterogeneity in canopy structure at the $15-30 \mathrm{~m}$ scale appears to have natural analogs in both young and old forests and should be incorporated in ecologically based forest management.

\section{Conclusion}

Researchers have observed that gaps and patches are fundamental units of forest organization in long-lived forests, and the theory of patch dynamics has provided a mechanism for understanding the dynamics of forest structure over time. Our data support the observation that patch structure proceeds through predictable stages. Following stand initiation, stands have complex patch structures (class 1) even though the sites in this stage in our study area had been replanted with the intention to produce uniform high-density stands. Following canopy closure, forest canopies become homogeneous and are dominated by one to a few spatially extensive patches of dense, low-rumple, and low-IJI patches (class 2). Over time periods that can span more than a century, sites develop canopies with vertical differentiation resulting in higher rumple but with few gaps (class 3). Disturbance eventually creates heterogeneous patch structures (classes 4-6). Differences in patch structure emerge from different combinations of structures at the gap and tree cluster scale (approximately our $30 \mathrm{~m}$ grid cell size) rather than from the development of canopy structures unique to different stand classes.

Our results raise the question as to what would be the appropriate scales from which to study stand structure or to plan silvicultural management to emulate natural disturbances. At the scale of individual $30 \mathrm{~m}$ grid cells, classes were distinct primarily on the basis of the proportion and arrangement of canopy structures and not on canopy structures unique to a class. Since our grid cells were similar in size to many field plots (0.09 ha) and identical to Landsat pixels, deducing the structure of a stand from a single or a few field plots or pixels could be problematic. The scale of measurements for stand structure could vary to match the patch structure. For our study area, structural variability in homogenous stands was captured at scales of $<30 \mathrm{~m}$, for matrix-patch stands at scales of $\sim 50 \mathrm{~m}$, and for patch mosaic stands at scales of 100-200 m.

We conducted this study to address the question of how the processes of patch dynamics cumulatively structure forests. As expected, we found that the development of struc- tural complexity and complex patch arrangement followed patterns predicted by established models of stand development. Two results surprised us. First, the rate at which stands develop gap and patch complexity varies tremendously between sites within the same watershed. Second, the high variance in patch-gap structure at larger scales appears to be an emergent property that is not a simple propagation of processes observed at smaller spatial scales. Future work can focus on the processes responsible for these results and further our understanding of how patch dynamics shapes forests.

\section{Acknowledgements}

This work was supported by NASA Headquarters under the NASA Earth and Space Science Fellowship Program (grant NNX07AN75H). The Watershed Services Division of Seattle Public Utilities, the King County Government of Washington State, and the Nature Conservancy of Washington State provided additional funding support. The Watershed Services Division of Seattle Public Utilities provided the LiDAR data used in the study. Michael Rosenberg gave permission to use a pre-release version of the PASSaGE 2 software and provided excellent support during the evaluation of different wavelet functions. Comments by Derek Churchill and R. Keala Hagmann and two anonymous reviewers improved earlier drafts of this manuscript.

\section{References}

Acker, S.A., Sabin, T.E., Ganio, L.M., and McKee, W.A. 1998. Development of old-growth structure and timber volume growth trends in maturing Douglas-fir stands. For. Ecol. Manage. 104(13): 265-280. doi:10.1016/S0378-1127(97)00249-1.

Birnbaum, P. 2001. Canopy surface topography in a French Guiana forest and the folded forest theory. Plant Ecol. 153(1-2): 293-300. doi:10.1023/A:1017563809252.

Bormann, F.H., and Likens, G.E. 1979. Pattern and process in a forested ecosystem. Springer-Verlag, New York.

Bradshaw, G.A., and Spies, T.A. 1992. Characterizing canopy gap structure in forests using wavelet analysis. J. Ecol. 80(2): 205-215. doi: $10.2307 / 2261007$.

Breiman, L. 2001. Random forests. Mach. Learn. 45(1): 5-32. doi:10. 1023/A:1010933404324.

Brosofske, K.D., Chen, J., Crow, T.R., and Saunders, S.C. 1999. Vegetation responses to landscape structure at multiple scales across a Northern Wisconsin, USA, pine barrens landscape. Plant Ecol. 143(2): 203-218. doi:10.1023/A:1009768115186.

Carey, A.B., Kershner, J., Biswell, B., and de Toledo, L.D. 1999. Ecological scale and forest development: squirrels, dietary fungi, and vascular plants in managed and unmanaged forests. Wildl. Monogr. 142: 5-71.

Connell, J.H. 1989. Some processes affecting the species composition in forest gaps. Ecology, 70(3): 560-562. doi:10.2307/1940205.

Crookston, N.L., and Finley, A.O. 2008. yaImpute: an R package for $k N N$ imputation. J. Stat. Softw. 23(10).

Dale, M.R.T., and Mah, M. 1998. The use of wavelets for spatial pattern analysis in ecology. J. Veg. Sci. 9(6): 805-814. doi:10. 2307/3237046.

Erckmann, J., Chinn, A., Flagor, S., Kurko, K., Freeman, J., Little, R., Schneider, G., and Vanderhoof, J. 2000. Final Cedar River Watershed Habitat Conservation Plan. City of Seattle, Seattle, Wash. Available from http://www.seattle.gov/util/About_SPU/ Water_System/Habitat_Conservation_Plan/AbouttheHCP/Documents/index.htm. 
Falkowski, M.J., Evans, J.S., Martinuzzi, S., Gessler, P.E., and Hudak, A.T. 2009. Characterizing forest succession with lidar data: an evaluation for the Inland Northwest, USA. Remote Sens. Environ. 113(5): 946-956. doi:10.1016/j.rse.2009.01.003.

Forman, R.T.T. 1995. Land mosaics: the ecology of landscapes and regions. Cambridge University Press, Cambridge, U.K.

Fortin, M.J., and Dale, M. 2005. Spatial analysis: a guide for ecologists. Cambridge University Press, Cambridge, U.K.

Franklin, J.F., and Dyrness, C.T. 1988. Natural vegetation of Oregon and Washington. Oregon State University Press, Corvallis, Ore.

Franklin, J.F., and Spies, T.A. 1991. Composition, function, and structure of old-growth Douglas-fir forests. In Wildlife and vegetation of unmanaged Douglas-fir forests. Edited by L.F. Ruggiero, K.B. Aubry, A.B. Carey, and M.H. Huff. U.S. For. Serv. Gen. Tech. Rep. PNW-GTR-285. pp. 71-80.

Franklin, J.F., and Van Pelt, R. 2004. Spatial aspects of structural complexity in old-growth forests. J. For. 102: 22-28.

Franklin, J.F., Spies, T.A., Van Pelt, R., Carey, A.B., Thornburgh, D. A., Berg, D.R., Lindenmayer, D.B., Harmon, M.E., Keeton, W.S., Shaw, D.C., Bible, K., and Chen, J.Q. 2002. Disturbances and structural development of natural forest ecosystems with silvicultural implications, using Douglas-fir forests as an example. For. Ecol. Manage. 155(1-3): 399-423. doi:10.1016/S0378-1127(01) 00575-8.

Fraver, S., White, A.S., and Seymour, R.S. 2009. Natural disturbance in an old-growth landscape of northern Maine, USA. J. Ecol. 97 (2): 289-298. doi:10.1111/j.1365-2745.2008.01474.x.

Frelich, L.E., and Lorimer, C.G. 1991. Natural disturbance regimes in hemlock-hardwood forests of the upper Great Lakes region. Ecol. Monogr. 61(2): 145-164. doi:10.2307/1943005.

Frelich, L.E., and Reich, P.B. 1995. Spatial patterns and succession in a Minnesota southern-boreal forest. Ecol. Monogr. 65(3): 325346. doi:10.2307/2937063.

Hemstrom, M.A., and Franklin, J.F. 1982. Fire and other disturbances of the forests in Mount Rainier National Park. Quat. Res. 18(1): 32-51. doi:10.1016/0033-5894(82)90020-5.

Henderson, J.A., Lesher, R.D., Peter, D.H., and Shaw, D.C. 1992. Field guide to the forested plant associations of the Mt. BakerSnoqualmie National Forest. U.S. For. Serv. Tech. Pap. R6-ECOLTP-028-91.

Ishii, H.T., Van Pelt, R., Parker, G.G., and Nadkarni, N.M. 2004. Age-related development of canopy structure and its ecological functions. In Forest canopies. Edited by M.D. Lowman, and H.B. Rinker. Elsevier Academic Press, Burlington, Mass.

Jentsch, A., Beierkuhnlein, C., and White, P.S. 2002. Scale, the dynamic stability of forest ecosystems, and the persistence of biodiversity. Silva Fenn. 36(1): 393-400.

Kane, V.R., Bakker, J.D., McGaughey, R.J., Lutz, J.A., Gersonde, R. F., and Franklin, J.F. 2010a. Examining conifer canopy structural complexity across forest ages and elevations with LiDAR data. Can. J. For. Res. 40(4): 774-787. doi:10.1139/X10-064.

Kane, V.R., McGaughey, R.J., Bakker, J.D., Gersonde, R.F., Lutz, J. A., and Franklin, J.F. 2010b. Comparisons between field- and LiDAR-based measures of stand structural complexity. Can. J. For. Res. 40(4): 761-773. doi:10.1139/X10-024.

Keitt, T.H., and Urban, D.L. 2005. Scale-specific inference using wavelets. Ecology, 86(9): 2497-2504. doi:10.1890/04-1016.

Kellner, J.R., and Asner, G.P. 2009. Convergent structural responses of tropical forests to diverse disturbance regimes. Ecol. Lett. 12(9): 887-897. doi:10.1111/j.1461-0248.2009.01345.x. PMID: 19614757.

Kembel, S.W., and Dale, M.R.T. 2006. Within-stand spatial structure and relation of boreal canopy and understorey vegetation. J. Veg. Sci. 17(6): 783-790. doi:10.1111/j.1654-1103.2006.tb02501.x.
Koukoulas, S., and Blackburn, G.A. 2004. Quantifying the spatial properties of forest canopy gaps using LiDAR imagery and GIS. Int. J. Remote Sens. 25(15): 3049-3072. doi:10.1080/ 01431160310001657786.

Larson, A.J., and Franklin, J.F. 2010. The tree mortality regime in temperate old-growth coniferous forests: the role of physical damage. Can. J. For. Res. 40(11): 2091-2103. doi:10.1139/X10149.

Larson, A.J., Lutz, J.A., Gersonde, R.F., Franklin, J.F., and Hietpas, F.F. 2008. Potential site productivity influences the rate of forest structural development. Ecol. Appl. 18(4): 899-910. doi:10.1890/ 07-1191.1. PMID:18536251.

Legendre, P., and Legendre, L. 1998. Numerical ecology. 2nd English ed. Elsevier, Amsterdam, The Netherlands.

Lertzman, K.P., Sutherland, G.D., Inselberg, A., and Saunders, S.C. 1996. Canopy gaps and the landscape mosaic in a coastal temperate rain forest. Ecology, 77(4): 1254-1270. doi:10.2307/ 2265594.

Lindenmayer, D.B., and Franklin, J.F. 2002. Conserving forest biodiversity: a comprehensive multiscaled approach. Island Press, Washington, D.C.

Lutz, J.A., and Halpern, C.B. 2006. Tree mortality during early forest development: a long-term study of rates, causes, and consequences. Ecol. Monogr. 76(2): 257-275. doi:10.1890/0012-9615 (2006)076[0257:TMDEFD]2.0.CO;2.

McElhinny, C., Gibbons, P., Brack, C., and Bauhus, J. 2005. Forest and woodland stand structural complexity: Its definition and measurement. For. Ecol. Manage. 218(1-3): 1-24. doi:10.1016/j. foreco.2005.08.034.

McGarigal, K., and Marks, B.J. 1995. FRAGSTATS. Spatial pattern analysis program for quantifying landscape structure. U.S. For. Serv. PNW-351.

McIntire, E.J.B., and Fajardo, A. 2009. Beyond description: the active and effective way to infer processes from spatial patterns. Ecology, 90(1): 46-56. doi:10.1890/07-2096.1. PMID:19294912.

North, M., and Keeton, W. 2008. Emulating natural disturbance regimes: an emerging approach for sustainable forest management. In Patterns and processes in forest landscapes. Edited by $\mathrm{R}$. Lafortezza, J. Chen, G. Sanesi, and T. Crow. Springer, New York. pp. 341-372.

Oliver, C.D., and Larson, B.C. 1996. Forest stand dynamics. Update ed. John Wiley \& Sons, New York.

Parish, R., and Antos, J.A. 2006. Slow growth, long-lived trees, and minimal disturbance characterize the dynamics of an ancient, montane forest in coastal British Columbia. Can. J. For. Res. 36 (11): 2826-2838. doi:10.1139/x06-166.

R Development Core Team. 2007. R: a language and environment for statistical computing. Available from http://www.R-project.org.

Rebertus, A.J., and Veblen, T.T. 1993. Structure and tree-fall gap dynamics of old-growth Nothofagus forests in Tierra-del-Fuego, Argentina. J. Veg. Sci. 4(5): 641-654. doi:10.2307/3236129.

Rosenberg, M.S., and Anderson, C.D. 2011. PASSaGE: pattern analysis, spatial statistics and geographic exegesis. Version 2. Methods Ecol. Evol. 2(3): 229-232. doi:10.1111/j.2041-210X. 2010.00081.x.

Runkle, J.R. 1982. Patterns of disturbance in some old-growth mesic forests of eastern North America. Ecology, 63(5): 1533-1546. doi:10.2307/1938878.

Runkle, J.R. 1992. Guidelines and sample protocol for sampling forest gaps. U.S. For. Serv. Gen. Tech. Rep. PNW-GTR-283.

Shugart, H.H. 1984. A theory of forest dynamics: the ecological implications of forest succession models. Springer, New York.

Shugart, H.H., Saatchi, S., and Hall, F.G. 2010. Importance of structure and its measurement in quantifying function of forest 
ecosystems. J. Geophys. Res. 115: G00E13. doi:10.1029/ 2009JG000993.

Sinton, D.S., Jones, J.A., Ohmann, J.L., and Swanson, F.J. 2000. Windthrow disturbance, forest composition, and structure in the Bull Run basin, Oregon. Ecology, 81(9): 2539-2556. doi:10.1890/ 0012-9658(2000)081[2539:WDFCAS]2.0.CO;2.

Smith, T.M., and Urban, D.L. 1988. Scale and resolution of forest structural pattern. Vegetatio, 74(2-3): 143-150. doi:10.1007/ BF00044739.

Spies, T. 1997. Forest stand structure, composition, and function. In Creating a forestry for the 21st Century: the science of ecosystem management. Edited by K.A. Kohm and J.F. Franklin. Island Press, Washington, D.C.

Spies, T.A. 1998. Forest structure: a key to the ecosystem. Northwest Sci. 72: 34-39.

Spies, T.A., and Franklin, J.F. 1991. The structure of natural young, mature, and old-growth Douglas-fir forests in Oregon and Washington. In Wildlife and vegetation of unmanaged Douglasfir forests. Edited by L.F. Ruggiero, K.B. Aubry, A.B. Carey, and M.H. Huff. U.S. For. Serv. Gen. Tech. Rep. PNW-GTR-285. pp. 91-109.

Spies, T.A., Franklin, J.F., and Klopsch, M. 1990. Canopy gaps in Douglas-fir forests of the Cascade Mountains. Can. J. For. Res. 20 (5): 649-658. doi:10.1139/x90-087.

Urban, D.L., Oneill, R.V., and Shugart, H.H.. 1987. Landscape ecology. Bioscience, 37(2): 119-127. doi:10.2307/1310366.

Van Pelt, R., and Nadkarni, N.M. 2004. Development of canopy structure in Pseudotsuga menziesii forests in the southern Washington Cascades. For. Sci. 50(3): 326-341.

Vehmas, M., Packalen, P., Maltamo, M., and Eerikainen, K. 2011. Using airborne laser scanning data for detecting canopy gaps and their understory type in mature boreal forest. Ann. For. Sci. 68(4): 825-835. doi:10.1007/s13595-011-0079-x.

Vepakomma, U., St-Onge, B., and Kneeshaw, D. 2008. Spatially explicit characterization of boreal forest gap dynamics using multitemporal lidar data. Remote Sens. Environ. 112(5): 2326-2340. doi:10.1016/j.rse.2007.10.001.

Vepakomma, U., Kneeshaw, D., and St-Onge, B. 2010. Interactions of multiple disturbances in shaping boreal forest dynamics: a spatially explicit analysis using multi-temporal lidar data and highresolution imagery. J. Ecol. 98(3): 526-539. doi:10.1111/j.13652745.2010.01643.x.

Vepakomma, U., St-Onge, B., and Kneeshaw, D. 2011. Response of a boreal forest to canopy opening: assessing vertical and lateral tree growth with multi-temporal lidar data. Ecol. Appl. 21(1): 99-121. doi:10.1890/09-0896.1. PMID:21516891.

Watt, A.S. 1947. Pattern and process in the plant community. J. Ecol. 35(1-2): 1-22. doi:10.2307/2256497.

Wiens, J.A. 1995. Landscape mosaics and ecological theory. In Mosaic landscapes and ecological processes. Edited by L. Hansson, L. Fahrig, and G. Merriam. Chapman and Hall, London, U.K.

Winter, L.E., Brubaker, L.B., Franklin, J.F., Miller, E.A., and DeWitt, D.Q. 2002. Canopy disturbances over the five-century lifetime of an old-growth Douglas-fir stand in the Pacific Northwest. Can. J. For. Res. 32(6): 1057-1070. doi:10.1139/x02-030.

Zenner, E.K. 2004. Does old-growth condition imply high live-tree structural complexity? For. Ecol. Manage. 195(1-2): 243-258. doi:10.1016/j.foreco.2004.03.026.

Zenner, E.K. 2005. Investigating scale-dependent stand heterogeneity with structure-area-curves. For. Ecol. Manage. 209(1-2): 87-100. doi:10.1016/j.foreco.2005.01.004. 